\title{
RESOLVING THE SUSTAINABLE FINANCE CONUNDRUM: ACTIVIST \\ POLICIES AND FINANCIAL TECHNOLOGY
}

\author{
EMILIOS AvgOULEAS*
}

\section{INTRODUCTION}

Our natural environment is severely affected by the impact of man-made climate change, resulting in the loss of biodiversity and shortages in food production and the availability of fresh water. At the same time, the outbreak of the COVID-19 pandemic and its devastating impact on public health and social and economic systems - including a massive depression of economic activity - has caused citizens, central banks, governments, and academics to rethink sustainable finance as something much more than climate change investment or a trendy industry term. While the outbreak of COVID-19 may itself be the product of human interference with nature, it is not the only challenge human societies face today. Racial, gender, and income inequality and the fate of liberal democracy are as important and should feature prominently in public debate and policy-makers' agendas.

Achieving these policy goals, as encapsulated in the United Nations (UN) Sustainability Development Goals (SDGs), ${ }^{1}$ requires substantial investment. The growing field of sustainable finance has sought to provide that funding, but the current funding gap remains enormous. This Article explains the funding gap as the product of three formidable obstacles: legal restrictions, the lack of a comprehensive framework for the monitoring and verification of the actual sustainability impact of green investments and policies, and finance models that narrowly measure investment risk and return. The latter often identify

Copyright $(\odot) 2021$ by Emilios Avgouleas.

This Article is also available online at http://lcp.law.duke.edu/.

* Chair in International Banking Law and Finance, University of Edinburgh; Vis. Professor, School of European Political Economy, Luiss Guido Carli; Member Securities and Markets Group, ESMA. Sincere thanks to Sir William Blair, Professor Steven Schwarcz, one of the editors of the present issue, and Professor Joseph Sifakis (Turing Prize, 2007) for invaluable comments and suggestions. All remaining errors are mine. Usual disclaimers relating to ESMA also apply.

1. Sustainable Development Goals, UNITED NATIONS, https://www.un.org/sustainabledevelop ment/sustainable-development-goals/ [https://perma.cc/3TC8-8ZPY] ("[The SDGs] are the blueprint to achieve a better and more sustainable future for all. They address the global challenges we face, including those related to poverty, inequality, climate change, environmental degradation, peace and justice. The 17 Goals are all interconnected, and in order to leave no one behind, it is important that we achieve them all by 2030.”). 
sustainable investments, especially in the developing world, as ones of high risk and low return. ${ }^{2}$ As I explain in Part III, these obstacles act like a dam with regards to sustainable finance flows. Arguably, the dam may only be breached if public policy takes a stronger role in actively encouraging sustainable investment through tax and regulatory incentives.

To implement that policy, an accord among G-20 countries, from which most private investment flows originate, is required. Any such accord should include agreed fiscal incentives and regulatory waivers for sustainable finance investments and sanctions or disincentives such as country-based levies to help important private actors and large asset managers to boost flows to the impact economy.

Arguably, a tax that treats capital flows that do not have a direct or indirect sustainability impact, for example investments in the carbon fuel industry, as a negative externality would constitute a radical departure from the more benign policies tried so far such as reporting and disclosure or pricing of carbon emissions. To be effective it would require international consensus. Such consensus already exists with respect to the provision of fiscal subsidies, such as discounts from the climate change levies for sustainable projects. ${ }^{3}$

Augmenting sustainable investment could provide a substantial boost to economic and employment recovery in the aftermath of the COVID-19 pandemic. ${ }^{4}$ Therefore, there has never been a better time to raise the prospect of reaching an international consensus on taxing non-sustainable investing and thus diverting those resources to the sustainable economy. While calls for a similar levy that would be used for development finance or to cut speculation in financial markets were also raised in the aftermath of the Global Financial Crisis of 2008-

2. The United Nations Environment Programme (UNEP) created a financial sector partnership programme nearly 30 years ago in the aftermath of the Rio Earth Summit in 1992. This eventually evolved into the UNEP Finance Initiative (UNEP FI). An influential UNEP FI report has noted: "Investment needs for the SDGs are huge, with the bulk in developing countries and their infrastructure. The scale of current financial flows is insufficient: private finance is constrained by risk and return requirements, while public finance is in scarce supply. If the resulting financing gap remains unresolved, investment needs will grow over time because of a cumulative effect... could business models be rethought in ways that would increase SDG serving financial flows, but also make them less risky?" U.N. ENV'T PROgRAMME Fin. InITIATIVE \& POSITIVE IMPACT InITIATIVE, RETHINKING IMPACT TO FINANCE THE SDGS 4 (2018), https://www.unepfi.org/wordpress/wp-content/uploads/2018/11/ Rethinking-Impact-to-Finance-the-SDGs.pdf [https://perma.cc/JC5J-ZVSW].

3. UN ENV'T PROGRAMME, BUILDING BACK BETTER: THE ROLE OF GREEN FISCAL POLICIES (June 2020), https://wedocs.unep.org/bitstream/handle/20.500.11822/32923/BBB.pdf [https://perma.cc/ 5L9J-6ZFC].

4. It has been calculated that impact economy investment including investing in innovative financial products that boost investment flows in the fields of energy, health, food and agriculture could "open up \$12 trillion of market opportunities in food and agriculture, cities, energy and materials, and health and well-being alone and create 380 million new jobs by 2030." Mara Niculescu, Impact Investment to Close the SDG Funding Gap, UN DEV. PROGRAMME: OuR PERSPS. (July 13, 2017), https://www.undp.org/content/undp/en/home/blog/2017/7/13/What-kind-of-blender-do-we-need-tofinance-the-SDGs-.html [https://perma.cc/JFD2-SEUT]. 
$2009^{5}$ and went nowhere, the result of the recent United States election in combination with the devastating impact of the pandemic may prove the watershed moment.

Moreover, cutting-edge financial technology encompassing artificial intelligence, machine learning ${ }^{6}$ (discussed more extensively in Part IV) and blockchain technology also can be critical in terms of boosting sustainable finance and creating a scientifically accurate environment for the allocation of the proposed here green taxes and subsidies among investment portfolios. First, measuring the impact of sustainable investments ex post through spatial finance ${ }^{7}$ analysis can verify the effectiveness of the investment and augment the credibility of sustainable finance products. Earth observations via satellites or drones and past image libraries can be processed though machine learning technology to provide relatively safe predictions about the impact of climate change on the land and habitats; coastal, rural, and metropolitan areas; arable land; deforestation; river and sea pollution levels; and the rest of the natural landscape.

Secondly, technology can also help to overcome another major obstacle: the problem presented by the characterization of sustainable investments as high risk and low return, under the traditional investment models. Only a radical reengineering of the mechanics of investing can deliver this change. In this context, this Article suggests that a number of clearly defined quantitative indicators could be incorporated into investment models to calculate the sustainability impact of an investment ex ante. These indicators and matrixes could help the asset management industry to evolve its investment practices to counter the adverse impact of standard risk and return models such as the Capital Asset Pricing Model (CAPM) ${ }^{8}$ on sustainable investing.

5. For the global initiative to tax financial transactions to fund development see https://www.robinhoodtax.org.uk [https://perma.cc/64G3-BUQ4]. For the potential of EU proposals for a Financial Transactions Tax (FTT), see Xavier Vives, A Rationale for the Tobin Tax, VoxEU blog (Feb.14, 2017), https://voxeu.org/article/rationale-tobin-tax [https://perma.cc/UPD8-DYH7]; Donato Masciandaro \& Francesco Passarelli, Is a European Tobin Tax Likely to be Efficient, VoxEU blog (Jan. 11, 2012), https://voxeu.org/article/european-tobin-tax-likely-be-efficient [https://perma.cc/B8NVJBE9].

6. Machine learning is a branch of artificial intelligence science that can process vast amounts of related and unrelated data and identify patterns through the use of a set of algorithms. Data analytics powered by machine learning algorithms is already widely used in the financial sector, especially in investment decision-making to both identify and measure risks and spot profit opportunities.

7. The term 'spatial finance' refers to the possibility of integrating geospatial data and analysis into financial theory and practice. "Combining Earth observation and remote sensing with AI can transform the availability of information in our financial system, and to change how risks, opportunities, and impacts are measured and managed by financial institutions and civil society." See Christophe Christiaen, Using Spatial Finance for Sustainable Development, REFINITIV: PERSPS. (June 10, 2020), https:// www.refinitiv.com/perspectives/ai-digitalization/using-spatial-finance-for-sustainable-development/ [https://perma.cc/C9EH-T729].

8. CAPM is a widely used model in finance to calculate beta, namely the desired return (R) of an asset for given Risk(Z) to make investment decisions in a portfolio. A given asset's sensitivity to nondiversifiable risk (also known as systematic risk or market risk) is represented by the quantity beta ( $($ ) measured against the expected return of the specific asset market or the expected return of a theoretical risk-free asset. 
With the advent of autonomous finance-by which I mean algorithm-driven financial services platforms that make decisions or take actions on investors' behalf $^{9}$ - gathering momentum in the form of so-called robo-advisors and algorithmic models for investment decision-making, ${ }^{10}$ there has never been a better time for such a shift in the mechanics of investing. While autonomous systems are far from having achieved a level of understanding and logic that would allow them to prioritize among several complex objectives ${ }^{11}$ still it is arguable that they can handle the additional complexity of increasing the number of decision-making dimensions of investing ${ }^{12}$ from two, namely, risk and return, to three, namely, risk, return and sustainability impact. ${ }^{13}$

This Article proceeds in four Parts. Part II provides information on sustainable development, and the current sustainable funding gap. Part III discusses the main contours of sustainable finance and the key obstacles to the desirable and required magnification of capital flows to sustainable investments. Part IV discusses two key financial technology solutions to the sustainable finance conundrum. Part V brings the different strands of the present analysis into a comprehensive solution.

9. See Peter Wannemacher \& Oliwia Berdak, Introducing Autonomous Finance: Forrester's New Research On Algorithm-Based Financial Services, FORRESTER (Aug. 15, 2019), https://go.forrester.com/ blogs/introducing-autonomous-finance-forresters-new-research-on-algorithm-based-financial-services/ [https://perma.cc/6JCP-UQ9F] (discussing the recent shift towards using autonomous services in the financial industry).

10. See Gaurav Sharma, "Autonomous-Finance" offers a Re-Imagined Idea of Banking, HACKERNOON (Nov. 3, 2019), https://hackernoon.com/autonomous-finance-offers-a-re-imagined-ideaof-banking-wiqs32fg [https://perma.cc/M5VV-BLJV] (providing a summary of autonomous finance impact on the future of baking and investing).

11. Autonomous systems can better adapt to complex environmental changes than the older control systems which are better suited "for static environments, where external disturbances and changes in internal parameters can be fully modulated... However, classical control systems are inadequate at addressing environmental uncertainty. By contrast, autonomous systems, which were first studied in the field of control systems, can be applied in an unknown environment." See Jerry Chen et al., Integrations Between Autonomous Systems and Modern Computing Techniques: A Mini Review, SEnsors, Sept. 2, 2019, No. 3897, at 1.

12. This belief has been premised on my reading of some recent works of Professor Joseph Sifakis, one of the founders of autonomous systems and 2007 Turing Award recipient. See Joseph Sifakis, Autonomous Systems - An Architectural Characterization, in ARXIV, https://arxiv.org/pdf/1811.10277.pdf [https://perma.cc/U5TD-T2TV] (2018); see also David Harel, Assaf Marron \& Joseph Sifakis, Autonomics: In search of a foundation for next-generation autonomous systems, 117 PROC. NAT'L ACAD. SCI. 17491 (2020).

13. While the essence of an autonomous (control) system is to address uncertainty, still autonomous systems have inherent limitations. Namely, they cannot be effective unless there is a clear hierarchy of goals. A good example comes from the case of driverless cars where the hierarchy can be as follows: passenger safety, pedestrian safety, car safety. But if it becomes more complex than that the system might stop responding in any predictable way and even become dangerous. This means the greater the number of goals the higher the possibility of system failure. See Chen et al., supra note 11, at 4. 
II

\section{THE SUSTAINABLE FUNDING GAP}

The United Nations (UN) promulgated in 2015 its Sustainable Development Goals (SDGs) $)^{14}$ which go much beyond the challenge of climate change to propose a number of key strategies to eradicate poverty, tackle gender and income inequality, and protect biodiversity. The SDGs, alongside the 2015 UN Paris Agreement on Climate Change (Paris Agreement) ${ }^{15}$ form the core of global strategies to promote sustainable development and social growth over time for the benefit of present and future generations.

The achievement of the SDGs and Paris Agreement objectives require the investment of vast sums. Therefore, sustainable finance-through direct investing and financial sector policies - has become a most critical means in the achievement of SDGs and the goals of the Paris Agreement. ${ }^{16}$ Governments in particular, and public policy in general-including economic growth, urban and country-side planning, fiscal, education, and social growth policies-are key in leveraging the impact of private sector initiatives to promote and boost sustainability.

When all of these actors move in unison, academic experts talk about a new type of economic paradigm: the impact economy. Investment to promote the impact economy largely overlaps with sustainable finance though it may have a more pronounced social market dimension. ${ }^{17}$ Therefore, sustainability impact is

14. G.A. Res. 70/1 (Sept. 25, 2015); see also Sustainable Development Goals, supra note 1.

15. Paris Agreement of the United Nations Framework Convention on Climate Change, Dec. 12, 2015, U.N. Doc. FCCC/cp/2015/10/Add.1; see also The Paris Agreement, UnITED NATIONS, https://unf ccc.int/process-and-meetings/the-paris-agreement/the-paris-agreement [https://perma.cc/6NZL-QLC8] (stating that the central aim of "The Paris Agreement ... is to strengthen the global response to the threat of climate change by keeping a global temperature rise this century well below 2 degrees Celsius above pre-industrial levels and to pursue efforts to limit the temperature increase even further to 1.5 degrees Celsius. Additionally, the agreement aims to strengthen the ability of countries to deal with the impacts of climate change").

16. Besides direct financing, four other major financial sector functions are essential to achieve the SDGs. These are financial inclusion, financing sustainable infrastructure and green energy, integrating ESG risk analyses in decision-making processes, and influencing clients to incorporate ESG criteria in their operations. See UNITED NATIONS GLOBAL COMPACT \& KPMG INT'L, SDG INDUSTRY MATRIX 8-9 (2015), https://home.kpmg.com/content/dam/kpmg/xx/pdf/2017/05/sdg-financial-services.pdf [https:// perma.cc/J8T5-GLC4]; see also OLAF WEBER, THE FINANCIAL SECTOR AND THE SDGs: INTERCONNECTIONS AND FUTURE DIRECTIONS 1 (2018), https://www.cigionline.org/sites/default/files/ documents/Paper\%20No.201web.pdf [https://perma.cc/6UTL-ZA9X].

17. McKinsey analysts note that the term "impact economy" means: "a very different kind of system from a traditional capitalist economy that prioritizes only financial returns. In an impact economy, consumers and shareholders will challenge entrepreneurs and executives to show that they generate their profits in a manner that contributes to the public good. This approach to doing business is already being enacted by some organizations on several levels ...." See David Fine, Hugo Hickson, Vivek Pandit \& Philip Tuienburg, Catalyzing the Growth of the Impact Economy, MCKINSEY \& Co. (Dec. 5, 2018), https://www.mckinsey.com/industries/private-equity-and-principal-investors/our-insights/catalyz ing-the-growth-of-the-impact-economy [https://perma.cc/W9PP-XTNP]; see also Dirk Schoenmaker, The Impact Economy: Balancing Profit and Impact, (Bruegel, Working Paper, 2020), https://www.bruegel.org/wp-content/uploads/2020/07/WP-2020-04-Impact-Economy-D.-Schoenmaker.

pdf [https://perma.cc/8257-JLZT]. 
defined here as the result of an action or of an investment that promotes both the SDGs and also wider social objectives, such as widening access to credit and financial inclusion. In Part III.B, I suggest a non-exclusive set of indicators that would make measurement of such impact quantifiable and concrete.

Sustainable investment-understood here to comprise financial products including green bonds, other forms of project funding, and equity investments in corporations with high Environmental, Social, and ESG ratings that strive to achieve sustainability - has experienced tremendous growth over recent years. Yet in terms of capital flows, sustainable investment lags much behind mainstream financial markets. The funding gap to achieve the SDGs' goals and the Paris Agreement targets is still enormous. ${ }^{18}$ In the European Union (EU) alone, the investment gap is calculated at around 180 billion euros. ${ }^{19}$ But the bulk of that gap is in developing countries where public finance is scarce and private finance is restrained by a continuous focus of investment model risk. ${ }^{20}$

Governments, central banks, and supra-national organizations like the European Commission-with the adoption of the European Green Deal ${ }^{21}$ and earlier initiatives $^{22}$ - and the $\mathrm{G} 20^{23}$ are trying to increase flows to sustainable finance funds and products through a host of policies. These include specially designed investment vehicles such as green funds and other measures and incentives including climate risk disclosure, product standardization and taxonomy. Some of these policies are discussed more extensively in Part III.

III

\section{The SustaInABLE FInANCE CONUNDRUM}

\section{A. Sustainable Finance: The Progress So Far}

As already mentioned, the raison d'être of sustainable finance is to fund the transition to a low-carbon, resource-efficient, sustainable economy to deal with the impact of climate change, to slow down or reverse climate change, and to create conservation societies that are sustainable.

18. According to the Organisation for Economic Co-Operation and Development (OECD) the global funding needs to meet the Paris Accord targets by 2031 are in the vicinity $\$ 6.5$ trillion, a colossal figure by all accounts. See ORG. FOR ECON. COOP. \& DEV., INVESTING IN CLIMATE, INVESTING IN GROWTH 15 (2017) [hereinafter OECD INVESTING].

19. See Communication from the Commission, Action Plan: Financing Sustainable Growth, at 2 COM (2018) 97 final (Aug. 3, 2018) [hereinafter EU ACTION PLAN].

20. OECD INVESTING, supra note 18.

21. In December 2019, the EU adopted its so-called Green Deal to make Europe carbon neutral by 2050. The Green Deal offers a roadmap for transitioning the EU's economy. One way the EU sets out to achieve this goal is by imposing legally binding targets for restoration of carbon-rich habitats. Another is by mobilizing at least $€ 1$ trillion of sustainable investments over the next decade. See Communication from the Commission, The European Green Deal, COM (2019) 640 final (Nov. 12, 2019).

22. EU Action Plan, supra note 19.

23. G20 Sustainable Fin. Study GrP., Sustainable FinanCE Synthesis Report (2018), http://unepinquiry.org/wp-content/uploads/2018/11/G20_Sustainable_Finance_Synthesis_Report_2018. pdf [https://perma.cc/L6BW-7W6T]. 
It is, thus, not surprising that the financial sector has increasingly been in the spotlight after the adoption of the SDGs and of the Paris Agreement in 2015.. Banks, capital market investors, and above all insurance corporations had to incorporate climate change risk into their risk assessment, decision-making, and disclosure frameworks. ${ }^{25}$ As a result, the sector has started managing proactively climate change risk by shifting portfolio investments to the low-carbon and climate-resilient economy. Also regulators and the private sector have developed robust ESG indicators and a strong reporting framework which have more or less merged with Corporate Social Responsibility (CSR) matrixes. ${ }^{26}$ In fact, ESG matrixes which measure the sustainability and societal impact of a company have become an inextricable tool in the determination of performance in several business sectors. ${ }^{27}$

First, companies that manage well their ESG issues are more likely to adapt their business models to promote sustainability, while protecting their competitive positions. This way they also grow their intangible assets such as market reputation and consumer confidence. ${ }^{28}$ The better their strategy anticipates the importance of sustainability, the more likely they are to be successful both in long-term economic and social value creation aided by the growth of the aforementioned intangible assets. Yet the move to sustainable business models requires companies not only to take care of the financial viability of their business model, but also to define and measure social benefits and environmental regeneration in an integrated way that incorporates financial, social, and environmental value.

Thus, it is not surprising that the heart of today's debate on the impact economy is the suggestion by influential think tanks and notable academics such

24. See generally EU High-LEVEL EXPERT GRP. ON SUSTAINABle Fin., FinANCING A SUSTAINABLE EUROPEAN ECONOMY, FINAL REPORT 2018 (2018), https://ec.europa.eu/info/sites/info/ files/180131-sustainable-finance-final-report_en.pdf [https://perma.cc/TRK6-W7PD]; UN ENV'T PROGRAMME FIN. INITIATIVE, https://www.unepfi.org [https://perma.cc/E32L-NH7H].

25. In fact, in January 2020, weeks before the advent of the COVID-19 pandemic the World Economic Forum's Global Risk Report had placed climate risk at the top of the long-term global threats. See WORLD ECON. F., THE GLOBAL RISKS REPORT 2020 fig.2 (2020), http://www3.weforum.org/ docs/WEF_Global_Risk_Report_2020.pdf [https://perma.cc/VN7B-XQLU].

26. See generally Edgar Löw, Deborah E. Klein, Adrian Pavicevac, Corporate Social Responsibility Reports of European Banks - An Empirical Analysis of the Disclosure Quality and its Determinants (Eur. Banking Inst. Working Paper Series, Paper No. 56, 2020) (providing an analytical account of CSR/ESG indicators how these support sustainability objectives and how they are observed by the EU banking sector).

27. " $92 \%$ of institutional investors would like corporations to report ESG factors that have a material effect on performance because they consider these factors in their decision-making process." Id. at 10 .

28. See generally DiRK SCHOENMAKER \& WILlEM SCHRAMADE, PRINCIPLES OF SUSTAINABLE FINANCE (2019). 
as Colin Mayer, ${ }^{29}$ Alex Edmans, ${ }^{30}$ and Steven Schwarcz ${ }^{31}$ that corporations should evolve from profit-maximizing entities into purpose-driven organizations. This coalition sees the purpose of the corporation as no longer one that is narrowly focused on shareholder value (profit maximization) but rather that of a body with a broader purpose and responsibility. Essentially, they view a restatement of corporate purpose as an ideological and psychological mechanism that will redirect corporate activity and resources to multiple value creation (financial, social and environmental). ${ }^{32}$

At the same time, sustainable investment has experienced tremendous growth over the recent years but still in terms of capital flows lags much behind mainstream financial markets. Stronger policies are required to persuade the financial sector to close the gap by motivating "asset owners and fund managers . . to adopt investment strategies that put still more emphasis on positive social outcomes." 33 Stronger policies are also necessary to cascade initiatives such as the United Nations-Convened Net-Zero Asset Owner Alliance. This is an international group comprising some of the world's biggest institutional investors with nearly $\$ 5.0$ trillion in assets under management, who have already made a bold commitment to transition their investment portfolios to net-zero greenhouse gas emissions by $2050 .{ }^{34}$

As I explain in Part III.B, a number of obstacles and industry investment practices act more or less as a dam with regards to the desirable increase in sustainable finance flows. For business and investment models to overcome the short-termism and narrow focus on investment risk and return, public policy has to shift from a strong yet passive encouragement of sustainable finance flows into active encouragement of sustainable investment. All the ESG reporting and socalled disclose-and-explain regulations such as the EU's recent investment products taxonomy and disclosure legislation, ${ }^{35}$ should be regarded as initiatives

29. See generally COLIN MAYER, PROSPERITY: BETTER BUSINESS MAKES THE GREATER GOOD (2018).

30. See generally Alex Edmans, Grow the Pie: How Great Companies Deliver Both PURPOSE AND PROFIT (2020).

31. See generally Steven L. Schwarcz, Misalignment: Corporate Risk-Taking and Public Duty, 92 NOTRE DAME L. REV. 1 (2016).

32. See SCHOENMAKER \& SCHRAMADE, supra note 28.

33. Fine et al., supra note 17.

34. The initiative demonstrates united investor action to align portfolios with a $1.5^{\circ} \mathrm{C}$ scenario, addressing Article 2.1c of the Paris Agreement. The present membership of the Alliance comprises Allianz, Caisse des Dépôts, La Caisse de dépôt et placement du Québec (CDPQ), Folksam Group, Pension Denmark, SwissRe, Alecta, AMF, CalPERS, Nordea Life and Pension, Storebrand, and Zurich. See United Nations-Convened Net-Zero Asset Owner Alliance, U.N. ENV'T ProgRAMme FIN. INITIATIVE, https://www.unepfi.org/climate-change/united-nations-convened-net-zero-asset-owner-allia nce [https://perma.cc/5NZJ-7PL5].

35. The Taxonomy is a tool to help plan and report the transition to an economy that is consistent with the EU's six environmental objectives: climate change adaptation, climate change mitigation, sustainable water and marine resources and their protection, transition to a circular economy, pollution prevention and control, protection and restoration of diversity and ecosystems. See EU TECHNICAL EXPERT GRP. ON SUSTAINABLE FIn., TAXONOMY: FINAL REPORT OF THE TECHNICAL EXPERT 
that passively encourage sustainable investment. In contrast, public policies that incorporate tax and regulatory incentives - including the lowering of regulatory requirements - to compensate creditors' and asset managers' portfolios for any foregone profit should be classified as active encouragement of sustainable investment or otherwise as sustainable finance activism.

As argued in this Article, the desirable shift in financial sector attitudes can be achieved much more effectively through a system of a tax subsidies and regulatory waivers employed to encourage sustainable investment as well as fiscal sanctions to discourage brown investments and short-termism. ${ }^{36}$ Employing public policy tools to achieve these objectives would also mean that short-term non-sustainable finance is viewed as an externality that ought to be eradicated through a system of Pigovian taxes. ${ }^{37}$

It is a view that many governments are hesitant to adopt. On the other hand, the Kyoto Protocol ${ }^{38}$ pricing approach that has been followed so far as the main means of halting human impact on climate change has proved ineffective. This view is further reinforced by the fact that, according to the World Bank, only 20 percent of global carbon emissions are currently covered by the Kyoto carbon pricing system and less than 5 percent of those are priced at levels consistent with reaching the goals of the Paris Agreement. ${ }^{39}$ Thus, pricing protocols and discloseand-explain policies ought to be supplemented by stronger measures.

Public sector tax subsidies and regulatory waivers can be calibrated on a rising scale based on the predicted-and actual-impact of a specific sustainable investment portfolio. All such subsidies can be subject to robust ex post

GROUP ON SUSTAINABLE FINANCE (2020), https://ec.europa.eu/info/sites/info/files/business_economy_ euro/banking_and_finance/documents/200309-sustainable-finance-teg-final-report-taxonomy_en.pdf [https://perma.cc/3AHK-WTRF] (discussing rationale, content, and reach of the EU taxonomy initiative).

36. Naturally actively discouraging investment brown investments, namely investment in the carbon fuel industry, might result in plant closures and widespread unemployment and adverse impact on communities depending on employment in the carbon industry. For this reason, it is essential for governments and International organizations like the World Bank to establish Just Transition Funds (or reinforce existing ones) that will help workers to retrain to become employable in other industries and support incomes and livelihoods during such transition.

37. The simplest definition of taxes and subsidies based on the analysis of externalities (costs not covered by the parties) of a market activity developed by English economist Arthur Cecil Pigou (18771959 ) is given by Wikipedia: "A Pigovian tax ... is a tax on any market activity that generates negative externalities (costs not included in the market price). The tax is intended to correct an undesirable or inefficient market outcome (a market failure), and does so by being set equal to the external marginal cost of the negative externalities ... Often-cited examples of such externalities are environmental pollution, and increased public healthcare costs associated with tobacco and sugary drink consumption ... Similar logic suggests the creation of a Pigovian subsidy to help consumers pay for socially-beneficial products and encourage increased production. An example sometimes cited is a subsidy for provision of flu vaccine." See Pigovian Tax, WIKIPEDIA, https://en.wikipedia.org/wiki/ Pigovian_tax [https://perma.cc/PQ6Z-XVVU].

38. See What is the Kyoto Protocol?, UN Climate CHANGE, https://unfccc.int/kyoto_protocol [https://perma.cc/WUW9-94CC].

39. See World BAnk GrP., State ANd TRends of CARbon Pricing 20193 (2019), http:// documents1.worldbank.org/curated/en/191801559846379845/pdf/State-and-Trends-of-Carbon-Pricing2019.pdf [https://perma.cc/LY4H-KHJV]. 
monitoring, and governments can implement clawbacks if the investment does not achieve the predicted impact for any reason other than, perhaps, force majeure.

The utilization of financial-technology-powered processes can respectively offer a way to forecast sustainability impacts ex ante and verify such impacts ex post. It could also help to measure how much profit an investment portfolio would have made with a lower percentage of green investments for the purpose of calculating the size of public subsidies. This would entail widespread use of modern technology by governments in both calibrating the subsidies, waivers, and sanctions as well as measuring any clawbacks, that is, payments that have to be returned due to failure to achieve the declared sustainability objectives of the investment. Asking governments to make resource allocation decisions using AI and ML technology, which, subject to the technology's inherent limitation of initial programing biases, are more or less immune to on-going pressure by interest groups, is not an entirely new call. ${ }^{40}$

But for the suggested policies to be successful, we must first map the key obstacles that sustainable finance flows face. For this reason, Part III.B offers a detailed mapping of the challenges, and Parts III.C and IV discuss how cuttingedge financial technology can help us identify and overcome them.

\section{B. Mapping the Obstacles}

As mentioned above, the three obstacles that prevent sustainable finance flows from reaching the required scale are legal restrictions, monitoring, and verification of sustainability impact, and risk and returns investment models which would often identify sustainable investments, especially in the developing world as ones of high risk and low return. ${ }^{41}$

Legal restrictions mostly refer to asset managers' fiduciary duties and investment mandates, which may hamper their ability to invest in sustainable products especially when higher yield mainstream financial products are available. In 2005, a United Nations Environment Program Finance Initiative (UNEP FI) report primarily authored by the London law firm Freshfields first declared what is today a widely shared belief, namely, that promoting sustainability is compatible with asset managers' fiduciary duties and in fact a key part of such duties. ${ }^{42}$ Beyond asset managers' wider social duty, investing in ESG compliant firms is regarded as good long-term investment policy, as such firms

40. For a previous suggestion on the use of AI for resource allocation by the administrative state and other related decisions thereby, see Cary Coglianese \& David Lehr, Regulating by Robot: Administrative Decision Making in the Machine-Learning Era, 105 GEO. L.J. 1147 (2017).

41. See OECD INVESTING, supra note 18.

42. U.N. ENV'T PROGRAMME FIN. INITIATIVE, A LEGAL FRAMEWORK FOR THE INTEGRATION OF ENVIRONMENTAL, SOCIAL AND GOVERNANCE ISSUES INTO INSTITUTIONAL INVESTMENT (2005), https: //www.unepfi.org/fileadmin/documents/freshfields_legal_resp_20051123.pdf [https://perma.cc/F9LE$63 \mathrm{TJ}]$. 
tend to be better managed, eschewing abusive or short-termist corporate tactics. ${ }^{43}$ But still statutory clarification is required. Moreover, investment mandates that focus on net financial return can be very restrictive on asset managers.

Given the absence of legislation that would resolve the fiduciary issue once and for all, questions remain vis-à-vis a possible conflict between asset managers' fiduciary duties to their beneficiaries and their willingness to promote sustainability impacts. Therefore, a new UNEP FI initiative is trying to investigate whether and how investors are, or can become, legally required to integrate the sustainability impacts of their investments in their decision-making processes. ${ }^{44}$ UNEP FI hopes that this on-going global survey will provide recommendations for policy change where analysis determines that legal obstacles are impeding asset managers from incorporating sustainability impact in their investment decision-making. ${ }^{45}$

While results of this survey are pending and the pace of law reform remains sluggish, two other questions arise that also seek pressing answers. They relate to the other two major obstacles. First, what is sustainability impact and how can it be measured within quantitative models with any degree of certainty? Secondly, if investors want asset managers to incorporate sustainability impact analysis in their investment decision-making, how can this be done in the most effective way? Both questions can be answered with reference to the ways financial technology can help to accurately measure sustainability impacts. The use of cutting-edge financial technology can lead to the creation of re-engineered investment models that take into account the potential sustainability impact of an investment.

A breakthrough like this would alter the internal mechanics of investing, which are currently solely pre-occupied with risk-and-return models due to the investment mandates as well as the configuration of the industry's promotion and remuneration structures, ${ }^{46}$ and tendency towards rent extraction. ${ }^{47}$ Therefore, the first step in such a policy shift is to identify possible ways to measure sustainability impacts.

43. See id. at 23 (explaining that "the use of positive screening for environmental, social, and ethical factors is entering mainstream investment analysis particularly where such screening may potentially yield superior financial performance by targeting companies that adopt socially responsible practices and thereby avoid future liabilities and losses").

44. The project was launched in January 2019 by the UN Principles of Responsible Investment (PRI) group, the UNEP FI and the Generation Foundation. See U.N. ENV'T PROGRAMME FIN. INITIATIVE, A LEGAL FRAMEWORK FOR IMPACT, https://www.unepfi.org/wordpress/wp-content/ uploads/2019/02/Legal-Framework-for-Impact_UNEPFI_PRI_Generation.pdf [https://perma.cc/5LD6XVRJ].

45. Id.

46. Two socio-economic studies stand out in this context. See generally DONALD MACKENZIE, AN Engine, Not a CAMERA: How Financial Models Shape Markets (2006); Diane-Laure ARJALIÈS ET AL., CHAINS OF FINANCE: HOW INVESTMENT MANAGEMENT IS SHAPED (2017).

47. See Emilios Avgouleas, Regulating Financial Innovation, in THE OXFORD HANDBOOK OF FINANCIAL INNOVATION 660, 665 (Niamh Moloney et al. eds, 2015). 


\section{How to Measure Impact and Why It Matters}

Developed by the founding members of the Positive Impact Initiative and released in 2017, the Principles for Positive Impact define sustainability impact in business and finance as "that which serves to deliver a positive contribution to one or more of the three pillars of sustainable development (economic, environmental and social), once any potential negative impacts to any of the pillars have been duly identified and mitigated." 48

A more recent UNEP FI initiative, Rethinking Impact to Finance the SDGs, lays out and develops the ideas behind the Positive Impact Initiative and is geared towards the "as-yet under-explored potential" of social, economic and environmental impacts to generate financial revenues via development of impact-based business models that boost long-term enterprise value. ${ }^{49}$ The UNEP FI has also suggested that the financial sector should incorporate two core features of an impact-based economy and adopt a holistic impact analysis that works back from impacts to come to the right investment decision, and achieves as many impacts as possible through each investment. ${ }^{50}$ This is probably the most encompassing approach to quantifying impact in a risk-and-return business and investment model framework and can be relevant to all stages of the investment chain, all sectors of the economy, and all types of financing. ${ }^{51}$

But the UNEP FI has not provided any concrete methodology as to how sustainable impact would translate into financial returns. Rather, by talking about a holistic approach to impact, it seemed to imply the possibility of adding to investment models a new independent variable to measure sustainability impact.

Sustainability impacts will have to be defined on the basis of quantifiable preset indicators, and the indicators must be capable of being measured with accuracy. This would allow sustainability impact to be part of advanced investment models. Thus, there is a need to develop distinct indicators for sustainability impact assessment. Still, a sustainability matrix or dashboard ${ }^{52}$

48. The Principles are intended to be applicable across all categories of financial instruments and the business activities that underpin them. See U.N. ENV'T PROGRAMME FIN. INITIATIVE, PRINCIPLES FOR POSITIVE IMPACT FINANCE 2 (2017), https://www.unepfi.org/wordpress/wp-content/uploads/2017/ 01/POSITIVE-IMPACT-PRINCIPLES-AW-WEB.pdf [https://perma.cc/K5UC-WH46] (defining Principle 1).

49. See U.N. EnV'T Programme Fin. InItiative, Rethinking IMPACT to FinANCE THE DGS 12 (2018), https://www.unepfi.org/wordpress/wp-content/uploads/2018/11/Rethinking-Impact-to-Finance -the-SDGs.pdf [https://perma.cc/3GUP-4VBE].

50. See supra note 48 .

51. UNEP FI rightly notes that the definition is also holistic-it covers the three economic, environmental and social pillars of sustainable development at the heart of the SDGs, from both positive and negative impact angles.

52. The term "dashboard" is used here to mean:

[A] tool used for information management and business intelligence... data dashboards organize, store, and display important information from multiple data sources into one, easyto-access place. Using data visualization, dashboards uniquely communicate metrics visually to 
should only encompass indices that can easily be quantified. Accordingly, this Article proposes the construction of a commonly accepted sustainability impact index. This proposal should be seen in light of World Economic Forum's (WEF) recent release of a standardized matrix for impact assessment on environment, social, and corporate governance. ${ }^{53}$

In this context an Organisation for Economic Co-Operation and Development (OECD) High Level Expert Group-chaired by eminent economists Joseph E. Stiglitz, Jean-Paul Fitoussi, and Martine Durand ${ }^{54}$-has developed a number of indicators to measure so-called "current and future wellbeing," which are, in part, capable of being quantified. ${ }^{55}$ The principal motivation of the Stiglitz Group was to shift the method for measurement of economic growth from standard Gross Domestic Product ratios analysis to a more encompassing approach that offers equal importance to several other indicators of well-being. ${ }^{56}$ It is true that many indicators about living conditions can be objective and easily observable and quantifiable. Good examples constitute indicators about income distribution among households, intra-household income distribution, and gender wealth gap. On the other hand, other indicators proposed by the Stiglitz group, like measurement of quality of life and equality of opportunity, may prove hard to quantify and thus would be hard to fit into sustainability impact dashboards. ${ }^{57}$

help users understand complex relationships in their data. In a data dashboard, it's easier to draw parallels between different but related metrics [and] identify trends ....

See What is a Dashboard, IDASHBOARDS, https://www.idashboards.com/guides/what-is-a-dashboard [https://perma.cc/8G9K-RDU7].

53. WEF published during its recent Sustainable Development Impact Summit a set of 21 sustainability metrics and guidelines after several years of work to address the need of the business community for global consistency and comparability to avoid the alphabet soup of competing metrics and piecemeal reporting that exists today. See generally WORLD ECON. F., MEASURING STAKEHOLDER CAPITALISM: TOWARDS COMMON METRICS AND CONSISTENT REPORTING OF SUSTAINABLE VALUE CREATION (2020), https://weforum.ent.box.com/s/lozzdf21sghth1ugijkclc1ere426hqv [https://perma.cc/ B3BR-HLVY]; see also Amanda Iacone, World Economic Forum Aims to Make ESG Reporting Mainstream, BLOOMBERG TAX (Sept. 22, 2020), https:/news.bloombergtax.com/financial-accounting/ world-economic-forum-aims-to-make-esg-reporting-mainstream [https://perma.cc/G8WM-L8G8] (stating that, according to the WEF, "[the metrics] represent perhaps the biggest step yet to rally companies, regulators, and standard-setters around a single set of ESG metrics and integrate them into mainstream financial reporting."); see also IFRS Foundation Trustees Consult on Global Approach to Sustainability Reporting and on Possible Foundation Role, INT'L FIN. STANDARDS REP. FOUND. (Sept. 30, 2020), https://www.ifrs.org/news-and-events/2020/09/ifrs-foundation-trustees-consult-on-globalapproach-to-sustainability-reporting/ [https:/perma.cc/B4QJ-LXK8] (assessing demand for global sustainability standards).

54. Measurement of Economic Performance and Social Progress: Members, OECD, https:// www.oecd.org/statistics/measuring-economic-social-progress/members.htm. [https://perma.cc/TU3PRTSC].

55. Joseph E. STIGLITZ ET AL., FOR GOOD MEASURE: ADVANCING RESEARCH ON WELL-BEING METRICS BEYOND GDP (2018).

56. RutGer HOEKSTRA, REPLACING GDP BY 2030: TOWARDS A COMMON LANGUAGE FOR THE WELL-BEING AND SUSTAINABILITY COMMUNITY 8-10 (2019).

57. See STIGLITZ ET AL., supra note 55. 
For this reason, I suggest the use of indicators such as income inequality, measured using the GINI index; ${ }^{58}$ gender inequality; human rights; and, as regards environmental progress, consumption-based carbon emissions and material-footprint-per-capita measures. ${ }^{59}$ Specific environmental indicators could even be combined with broader measures like the Ecological Footprint indicator, ${ }^{60}$ which "accounts for human demand on global biological resources [and] compares the level of consumption with the available amount of bioproductive land and sea area." ${ }^{61}$

It is, of course, incumbent on International organizations such as the OECD and the World Bank to endeavor to standardize the measurable indicators of a sustainability impact index. Then each investment would be scored for its predicted contribution and impact on the promotion of SDGs, including, but not limited to, preservation of biodiversity, promotion of gender and income equality, and poverty reduction.

Subsequently, the proposed impact index could be incorporated into sustainable investment models, namely models that would offer a clear indication of the interplay among expected or forecasted risk, return, and sustainability impact of an investment. Any clearly foregone profit would then be compensated through fiscal subsidies, tax waivers, and lowering of costly regulatory requirements. Arguably, a shift of this kind in investment modelling, incentivized by public subsidies, will radically alter the internal mechanics of investing and the main goals of the investment industry.

IV

\section{UTILIZING FinANCIAL TECHNOLOGY TO Boost SustainABLE FinANCE} FLOWS

\section{A. Measuring Climate Risk and Sustainability Impact}

The Task Force on Climate-Related Financial Disclosures-chaired by Michael Bloomberg - has developed a widely adopted framework for reporting on governance, strategy, risk management, and metrics and targets relevant to

58. Developed by the Italian statistician Corrado Gini in 1912 the Gini index is a measure of the distribution of income across a population. It is often used as a gauge of economic inequality, measuring income distribution or, less commonly, wealth distribution among a population. A higher Gini index indicates greater inequality, with high income individuals receiving much larger percentages of the total income of the population. WORLD BANK, DEV. RSCH. GRP., Gini index (World Bank estimate), https:// data.worldbank.org/indicator/SI.POV.GINI [https://perma.cc/SG2Z-CFKT] (providing a country-bycountry estimate of the Gini index).

59. See Schoenmaker, supra note 17; see also John Hickel, The Sustainable Development Index: Measuring the Ecological Efficiency of Human Development in the Anthropocene, ECOLOGICAL ECON., Jan. 2020, No. 106331 (proposing a Sustainable Development Index that accounts for CO2 emissions and material footprint).

60. See Thomas Wiedmann \& John Barrett, A Review of the Ecological Footprint IndicatorPerceptions and Methods, 2 SUSTAINABILITY 1645 (2010).

61. Id. at 1646. 
climate-related risks and opportunities. ${ }^{62}$ However, disclosure alone is not enough to integrate biodiversity into financial decision-making across portfolios.

Climate change is affecting all aspects of finance: credit, capital markets, and insurance. At the same time, a wealth of data, tools, frameworks and other resources have been or are being developed to support financial institutions in assessing biodiversity-related risks and reporting on their efforts to mitigate and manage these risks. The proliferation of spatial information and data, cloud computing, and machine learning algorithms can provide evidence about the environmental and social context of investments, leading to both better pricing of risk and better targeting of how financial flows would leverage impact. Meanwhile the cost of conducting such analysis is ever decreasing while computing power is expected to keep increasing. In the course of the decade, cloud computing will become faster and more efficient, allowing for ever greater data collaboration projects.

Utilizing earth observation and remote sensing combined with machine learning has the potential to transform the availability of environmental and social impact information, allowing financial markets to better measure and manage climate-related risks alongside a range of other factors that affect risk and return in different asset classes. ${ }^{63}$ Spatial finance can have a profound impact on the way banks assess climate risks when they lend money and insurers insure housing, corporate, and investment risks. But spatial finance can go beyond augmenting the quality of pricing and hedging of climate change risk. If used properly it can revolutionize on-going and ex post monitoring of sustainable finance projects as well as offering credible and valuable scrutiny and verification of ESG reporting resolving the problem of evidencing the impact of sustainable investments and policies. $^{64}$

It has been suggested - I believe accurately - that utilizing geo-observation data to identify climate change is a project of equal significance to the decoding of the human genome and should be similarly undertaken in a collaborative way through inter-linked databases. At the same time, as the partners of the Spatial Finance Initiative observe ${ }^{65}$ "publicly available, consistent, and comparable asset-level datasets are urgently needed for actors across the financial system" to manage the risk and return of investment portfolios and their impact on local and global ecosystems. ${ }^{6}$ As they note, keeping relevant datasets and processing them via

62. See generally TASK FORCE ON ClimATE-RELATED FIN. DisClosures, FinAL REPORT: RECOMMENDATION OF THE TASK-FORCE ON CLIMATE-RELATED FINANCIAL DisCLOSURES (2017), https://assets.bbhub.io/company/sites/60/2020/10/FINAL-2017-TCFD-Report-11052018.pdf [https:// perma.cc/CBE5-DDVJ].

63. See Christiaen, supra note 7.

64. See Opinion, William Blair, Emilios Avgouleas, How Spatial Finance Can Boost Climate Change Fight Through Better Environmental Predictions, S. CHINA MORNING POST, Oct. 21, 2020.

65. SPATIAL FIN. INITIATIVE, https://spatialfinanceinitiative.com [https://perma.cc/46S5-5G7Z].

66. GeoAsset, SPATIAL FIN. INITIATIVE, https://spatialfinanceinitiative.com/geoasset-project/ [https://perma.cc/C7HF-W8VC]. 
machine learning ${ }^{67}$ could help monitor "climate risk, ESG transparency and verification, inequality, human and ecosystem health, disaster response, and infrastructure development." 68

It follows that the combined use of learning algorithms on a vast array of connected databases can provide relatively accurate predictions about the impact of climate change on land and habitats; coastal, rural, and metropolitan areas; arable land; deforestation, river and sea pollution levels, et cetera. It can also have a profound impact on the way banks assess climate risks when they lend money and insurers insure housing, corporate, and investment risks. For public authorities, spatial finance can become the key mechanism for the effective incorporation of climate risk into the framework for on-going bank prudential supervision of climate risks and make periodic stress testing of bank lending portfolios against climate change risk rather accurate and credible.

\section{B. Sustainability Impact And 3D Investment Models}

Asset managers decide their investment strategies-asset allocation in a portfolio-mainly on the accepted rate of return for given risk and optimal diversification. These are derived through the use of mathematical abstractions or models which are "designed to represent (a simplified version of) the performance of a financial asset or portfolio of a business, project, or any other investment." ${ }^{69}$ The most popular investment models measure the return of investments on the basis of Net Present Value (NPV), essentially the assets' future cash flows discounted by a risk-free rate (DCFs). The already discussed CAPM and the so-called Arbitrage Pricing Theory (APT) are the predominant models used by asset managers to calculate DCFs (that is, a given asset's NPV) are. ${ }^{70}$ Normally, both models are used in order to offset inconsistencies created by the abstractions of either model and they are both linear. ${ }^{71}$ However, finance

67. Information imported from satellite and other means of aerial observation and connected databases can exponentially increase the amount of data available to the financial sector about climate change and loss of biodiversity. Combining now this data with machine learning we can transform the accuracy of climate change risk calculations in the entire financial sector: lending, investment, insurance. SPATIAL FIN. INITIATIVE, supra note 71.

68. Id.

69. Financial Modeling, WIKIPEDIA, https://en.wikipedia.org/wiki/Financial_modeling [https:// perma.cc/8ZTA-AHEW].

70. APT is a theory of asset pricing that measures a financial asset's expected return as a linear function of various factors or theoretical market indices. The sensitivity of modelled expected returns to changes in each factor is represented by so-called beta coefficient. The resulting rate of return is used to price the asset and the resulting asset price should equal the expected end of period price discounted at the rate implied by the model. Where the price diverges, arbitrage between different assets or different markets will eliminate the anomaly. See generally Stephen A. Ross, The Arbitrage Theory of Capital Asset Pricing, 13 J. ECON. THEORY 341 (1976).

71. "Linear models describe a continuous response variable as a function of one or more predictor variables." Linear Model, MATHWORKS, https:/uk.mathworks.com/discovery/linear-model.html [https://perma.cc/3RK9-XD22]. 
professionals also use non-linear or so-called stochastic models to capture random events that linear models cannot capture. ${ }^{72}$

It is, nonetheless, increasingly paradoxical that a very complex system like finance is principally seen through the simple prism of risk and return when it comes to investment allocation decisions, without attempting to measure other impacts the investment might have. This starkly contrasts with the way developments are forecasted and measured in most other complex systems such as molecular growth in biology or weather systems or climate change. ${ }^{73}$

From the use of stochastic models to fractals, finance is using ever more complex and advanced forecasting models that, in their attempt to capture financial market developments, try to imitate as much as possible forecasting models used in physics. Yet the finance industry's adherence to two-dimensional finance models has survived for more than half a century, in contrast to the evolution of forecasting models in natural sciences. Similarly, the perceived lack of synchronicity of CAPM models - namely that an investment is mostly assessed by reference to NPV, ${ }^{74}$ whereas sustainability impacts are assessed over time - is a false assumption. Most investment professionals today use so called I-CAPM, an inter-temporal CAPM model developed by Robert Merton, joint recipient of the 1997 Nobel prize in economics, which is a more realistic approach of how investors build their portfolios over a number of years to shape their strategy as market conditions and risks change over time. ${ }^{75}$ Investment portfolios based on I-CAPM hedge against inter-temporal market risk, including unexpected market reversals such as company or industry downturns, high unemployment rates, or geopolitical tensions. ${ }^{76}$ Therefore, the argument about the impossibility of synchronizing time-wise between predictions of investment risk and return and of sustainability impacts is inapplicable.

72. In finance stochastic models are used to predict random outcomes on the basis of forecasts of the probability of various outcomes under different conditions, using random variables. They are thus contrasted with linear models that retain the constancy of predictor variables.

73. Wikipedia describes General Circulation Models (GCMs) as follows: "Three-dimensional (more properly four-dimensional) GCMs apply discrete equations for fluid motion and integrate these forward in time. They contain parameterizations for processes such as convection that occur on scales too small to be resolved directly. A simple general circulation model (SGCM) consists of a dynamic core that relates properties such as temperature to others such as pressure and velocity. Examples are programs that solve the primitive equations, given energy input and energy dissipation in the form of scale-dependent friction, so that atmospheric waves with the highest wave numbers are most attenuated." General Circulation Models, WIKIPEDIA, https://en.wikipedia.org/wiki/General_ circulation_model [https://perma.cc/5TSY-SKRL].

74. CAPM utility functions treat only first and second moments as material or alternatively calculation of asset returns is premised on probability distributions are completely described by the first two moments.

75. Robert C. Merton, An Intertemporal Capital Asset Pricing, 41 ECONOMETRICA 867, 869 (1973).

76. "Some investments or asset classes may historically perform better in bear markets, and an investor may consider holding these assets if a downturn in the business cycle is expected. An investor who uses this strategy may hold a hedge portfolio of defensive stocks, those that tend to perform better than the broader market during economic downturns." Will Kenton, Intertemporal Capital Asset Pricing Model, INVESTOPEDIA (Apr. 9, 2020), https://www.investopedia.com/terms/i/intertemporal-capitalasset-pricing-model-icapm.asp [https://perma.cc/UJ6R-RPGX]. 
It follows that, given the wealth of historical data we already have on yield differences between speculative, long-term, ESG, and social market investment, ideally an enlightened policy-maker could fashion a system of regulatory and tax incentives that would subsidize sustainable investment and also penalize forms of finance that do not fall into this bracket - such as brown investment or short-term corporate-to-corporate lending; the latter long regarded as destabilizing. Close monitoring through the use of spatial finance analysis would allow policy-makers to claw back subsidies and tax breaks and to countermand any regulatory waivers, if the investment in question was misdirected-for example in an area such as social housing where the investment ends up to be exploitative to owners or tenants - or failed to produce the intended impact due to the negligence of one of the key actors - funders, issuers, manufacturers, or builders, among others.

Any differences in predicted returns could be used to quantify the fiscal subsidy of a sustainable portfolio. In addition, based on expected returns, diversification rates, and historical performance, regulators could undertake to fine-tune capital, liquidity, and large exposure requirements for sustainable finance by banks and investment funds. That would provide further relief on the operating costs of these institutions as well as incentives to direct additional resources to the achievement of SDGs and of the objectives of the Paris Agreement.

\section{$\mathrm{V}$ \\ CONCLUSION}

Capital flows directed to the achievement of the UN SDGs and of the objectives of the Paris Agreement form the core of sustainable finance and impact economy funding. At the same time, ecosystem resilience, investment diversification, and battling economic and social inequality - and digital exclusionare the keys to the prosperity of post-COVID-19 societies and the best way for them to avoid a plunge into the barbarism of poverty; xenophobia; gender, racial and income inequalities; and economic nationalisms which threaten the very foundations of our liberal democracies.

Humanity today stands at critical cross-roads, not just with regards to climate change and loss of biodiversity but also regarding all the other social and economic illnesses targeted by the UN SDGs. The tide may only be reversed through a shift in public policy implementing an activist framework for sustainable finance that goes beyond carbon pricing and labelling or standardization. Given the persistence of the discussed funding gap, a more radical approach is required vis-à-vis governments' attitude towards investments that do not have a sustainability impact. Fiscal and regulatory policies that include levies, subsidies, and waivers are arguably the most drastic way to reposition capital resources and implicitly delegitimize brown investing. But we need a G-20 Accord to sanction such a shift in public policy to also avoid regulatory and fiscal arbitrage.

The devastating human and economic toll of the COVID-19 pandemic also presents the right window of opportunity. Furthermore, combined with a shift in 
public policies or even independently of that, the utilization of cutting-edge financial technology can revolutionize the internal mechanics of investing within the financial sector and the way we measure and monitor sustainability impacts. In this context, this Article and the present issue of Law and Contemporary Problems can start a very fruitful policy dialogue and stimulate a research agenda that will break new ground towards a radical redirection of sustainable finance research and policymaking. 